capacity, even if it does no more than an arithmometer, he will, by demonstrating its practicability and advantages, be more likely to be enabled to procecd step by step to the more perfect instrument than he will if, as Babbage did, he imagines his whole machine at o.nce. In the writer's opinion, the ingenuity required to arrange a complete analytical engine is really in great part misplaced. Such a machine can only be used and kept in order by someone who really understands it, and it would seem to the writer of this notice more practicable to allow the user's attention to replace the action of operation cards, and leave to the machine the more direct numerical evaluations. C. V. Boys.

\section{PROF. D. J. CUNNINGHAM, F.R.S.}

$T H E$ death of this eminent anatomist occurred on Wednesday of last week, June 23. It was known that Prof. Cunningham had been ill for several months, but the fatal nature of the illness was not at first recognised, and the news of his untimely death in the full vigour of his powers will have come as a shock to many of his friends, and their name is legion.

Daniel John Cunningham was born in April, I850, at Crieff, where his distinguished father, who was later to become principal of St. Andrew's University, was then the mirister. His school days were passed at Crieff Academy. At the age of seventeen he was sent to Edinburgh University, and began the study of medicine. Here he had a brilliant career as a student, and in 1874 took his M.B. degree with firstclass honours. In ${ }_{1} 876$ he proceeded to the M.D. degree, the subject of his thesis being "The Anatomy of the Cetacea"; for this he was awarded a gold medal. His work on this subject was performed in the anatomical department of the university, where he was acting as assistant demonstrator to Prof, Turner; the influence of the master is apparent in the work of the pupil.

In 1876 Cunningham became principal demonstrator of anatomy, a position of much responsibility, as well as of great advantage to the holder from the experience in anatomical work and in teaching which it offers. Of this experience he took full advantage, and his high qualifications were recognised when he was appointed in 1882 to the chair of anatomy in the Royal College of Surgeons in Dublin. This appointment was not long held by him, for in the following year his services were transferred to the much more important chair of anatomy in Trinity College. Here he remained until 1903, when, on the retirement of Sir William Turner from the professorship of anatomy in the University of Edinburgh, it was felt that there was only one man worthy to succeed him, and the invitation which was tendered to him by the Curators of Patronage was, not without some hesitancy, accepted by him.

The hesitancy-even in view of the higher emolument and larger sphere of usefulness which the appointment to his Alma Mater involved-is not difficult to understand. For Cunningham had endeared himself to Dublin by many close ties; he was the centre of a large circle of intimate friends, and his influence and interests were in no way confined within the walls of the university, but extended to all circles of society. For several years he acted as secretary, and for some time as president, to the Royal Zoological Society of Ireland, and the effect of his work is apparent in the splendid condition of their menagerie, which is, for its size, probably the most successful in Europe. He was a constant attendant at the famous Saturday morning breakfasts of the council, and on leaving NO. 2070, VOL. 8I]
Dublin for Edinburgh was the recipient of a silver bowl engraved with the signatures of his fellowmembers, a testimonial which he prized with pleasurable pride. During four years he was honorary secretary to the Royal Dublin Society. He was frequently consulted on scientific questions by the Viceregal Government, who in 1900 appointed him a member of the commission to inquiry into the condition of the inland fisheries of Ireland. In the same year he was sent out to South Africa as a member of the Royal Commission to inquire into the care of the sick and wounded in the war. He also served on a War Office committee to report on the physical standards required for candidates for commissions and recruits.

But the performance of these public duties was not allowed to interfere with his scientific work. Both before and after his appointment to Dublin his communications on anatomical subjects were numerous and important. His text-books on "Practical Anatomy" and on "Systematic Anatomy "--the latter edited and in part written by himself-have a large cireulation. His " Memoir on Cornelius McGrath, the Irish Giant," which was published by the Royal Irish Academy in $189 x$, is a model of exact anatomical description, and was influential in pointing to the analogies between the conditions of gigantism and those met with in acromegaly, a disease to which attention had shortly before been directed by Marie, who was the first to associate it with tumour of the pituitary body. No less important is his "Memoir on the Surface Anatomy of the Cerebral Hemispheres," which was published in 1892 . In 1902 he delivered the Huxley memorial lecture before the Anthropological Institute, the subject of the lecture being " Righthandedness and Left-brainedness."

On his transference to Edinburgh in 1903, Cunningham's activities were in no way diminished, and his influence was immediately felt both in the university and in scientific and medical circles of the city. His genial personality at once won the hearts of the students, who were no less attracted by his powers of exposition. The confidence of his colleagues was manifested by his early election to fill the position of dean of the faculty of medicine. This confidence proved well-merited, for, under his auspices, the scheme of reform of the medical curriculum which had been for years in a condition of suspended animation was re-invigorated, and before long passed through all its stages, which in a Scotch university are more complex and difficult than those of a Bill in Parliament. As a member of the council and as secretary of the meetings, he took an active part in the work of the Royal Society of Edinburgh, and was instrumental in improving the form and character of its published Proceedings. He effected a similar change in the Journal of Anatomy and Physiology, of which he became acting editor, and to which he had always, either personally or through his pupils, been in the habit of contributing articles. He continued to take a keen interest in the public services, and was prominent in the movement for the establishment of a medical equipment of the Territorial Force in the East of Scotland.

Cunningham's eminence in science has been recognised on many occasions. He was elected in $180 \mathrm{r}$ to the Fellowship of the Royal Society, and in 1898 served on its council. The Universities of Dublin, Oxford, St. Andrews, and Glasgow conferred upon him their honorary degrees. He was president of the Anatomical Society and of the anthropological section of the British Association, and at various times was examiner in most of the universities of the United Kingdom.

Of Cunningham's personal character it is impossible 
to speak too highly. Of his fine, manly figure; his frank, open countenance; his clear, honest, kindly eyes; his disposition, genial but firm; his humour, devoid of cynicism; his loyalty to his friends; his gentleness even to opponents, all who had the privilege of knowing him will for ever retain a bright remembrance. As a writer in the Scotsman truly says :- "To the University and to science his death is nothing short of a calamity, while to his friends it has brought a sense of desolation."

$\mathrm{He}$ was interred on Saturday afternoon at Edinburgh. His remains were escorted from the Church of St. Cuthbert by a long line of students, colleagues, representatives of learned societies, and personal friends, the melancholy procession offering a strong contrast to the gaiety of the city, the traffic of which was arrested by its passage. He lies in the beautiful Dean Cemetery, than which few places contain more distinguished dust. Requiescat in pace.

\section{DR. G. F. DEACON.}

THE death of Mr. G. F. Deacon, a member of the council of the Institution of Civil Engineers, and eminent for his scientific work in engineering, was announced in last week's NATURE. Mr. Deacon, during his comparatively short life-he died at the age of sixty-six-obtained a considerable reputation as a water-works engineer, and is best known by his connection with the Vyrnwy Reservoir for the supply of Liverpool. In 1876 the need had arisen for an additional supply of water, and Mr. Deacon, who was then acting as municipal and water engineer, was instructed by the corporation to make an investigation as to the locality from which an additional supply could be obtained. After a survey of several sources he finally advised that this could be best obtained from the River Vyrnwy, a tributary of the Severn, situated in North Wales. Mr. Deacon's recommendation was submitted to Mr. Thomas Hawksley and Mr. Bateman, who approved this choice. The Bill promoted by the corporation having received the sanction of Parliament, Mr. Deacon was appointed joint engineer with Mr. Hawksley to prepare the plans and carry out the work. When the works were about half finished, Mr. Hawksley retired, and Mr. Deacon was left in sole charge.

The Vyrnwy works are remarkable as having the largest reservoir in England, and the first to have a high water-tight masonry dam. This dam was formed with blocks of clay slate from the Caradoc beds of the lower Silurian formation, some of which weighed ro tons. These were set in mortar composed of Portland cement and slate stone crushed fine enough to pass through meshes of one-eighth of an inch. The dam is $135^{\circ}$ feet long, 136 feet high, and impounds the water in a reservoir 5 miles long and covering I I 2 acres. The cost of these works was $2 \frac{1}{2}$ million pounds, and they were carried out under Mr. Deacon's supervision without the aid of a contractor. A full account of the Vyrnwy works is given in a paper read by $\mathrm{Mr}$. Deacon at the Institution of Civil Engineers in 1896 , and contained in vol. cxxvi. of the Minutes of Proceedings.

Mr. Deacon was educated at the Glasgow University, which subsequently conferred upon him the honorary degree of LL.D. He served his time in Napier's shipyard, which led to his becoming one of Lord Kelvin's assistants on the Great Eastern when an attempt was made to lay an Atlantic cable. At the age of twenty-two he commenced practice as an engineer at Liverpool, and six years afterwards was appointed municipal and water engineer of that borough. One of the most important services he renNO. 2070, VOL. 8I] dered during this time was the invention of the wastewater meter, by means of which it became possible to locate the place where leakage and waste were going on in the mains or from the service pipes, and thus a very great saving was effected in the quantity of water required. He also devised considerable improvements in the instruments used for measuring the velocity of the flow of water in rivers, and applied the use of electrical mechanism to current meters. He took keen interest in devising and improving the means of making the meteorological observations necessary for determining the yield of rain water.

In $1879 \mathrm{Mr}$. Deacon resigned his appointment as municipal engineer in order to devote his whole time to the Vyrnwy works. On the completion of these he commenced to practise at Westminster as a consulting engineer, and was connected with many important schemes of water supply, and frequently was engaged in giving evidence before parliamentary committees. In addition to his work as a water-works engineer, $\mathrm{Mr}$. Deacon applied a considerable amount of attention to the application of scientific principles to the solution of problems arising out of the practical work of the engineer.

$\mathrm{Mr}$. Deacon was president of the engineering section of the British Association at the meeting held at Toronto in 1897 , also of the Municipal and County Engineers at their meeting in 1878 . He was a Fellow of the Meteorological Society, and a member of the Institution of Mechanical Engineers.

\section{NOTES.}

TIIE list of honours announced on the occasion of the celebration of the King's birthday on Friday last includes the names of five Fellows of the Royal Society. Mr. Francis Galton, F.R.S., Prof. J. Larmor, F.R.S., Mr. R. H. I. Palgrave, F.R.S., and Prof. T. E. Thorpe, F.R.S., have received the honour of knighthood, and Dr. W. Schlich, F.R.S., has been appointed a Knight Commander of the Order of the Indian Empire (K.C.I.E.). Other men of distinction in the scientific world included in the list are:-Mr. Edgar Thurston, superintendent of the Government Central Museum, Madras, appointed a Companion of the Order of the Indian Empire (C.I.E.); Prof. W. J. R. Simpson, a Companion of the Order of St. Michael and St. George (C.M.G.); Sir Dyce Duckworth and Mr. Henry Morris, president of the Royal College of Surgeons, have had baronetcies of the United Kingdom conferred upon them; and Mr. James Stuart, who founded the system of university extension and the mechanical workshops at Cambridge, has been made a privy councillor.

ON Monday evening Mr. E. H. Shackleton delivered his first lecture since his return home on the results of his South Polar expedition at a special meeting of the Royal Geographical Society in the Royal Albert Hall. The main facts of the expedition have already been recorded in our own columns and elsewhere, but a large and brilliant audience assembled to hear from the explorer's own lips an account of the experiences of his eompanions and himself during their fourteen months' sojourn within the Antarctic circle. It is not always easy to realise the meaning of distances between places the position of which is only known in terms of latitude and longitude, and Major Leonard Darwin, who presided over the meeting, performed a useful service for his audience by indicating the extent of ground which would have to be covered by a party starting from London northwards on a journey of the same length as that which took Mr. Shackleton 